\title{
Glutathione peroxidases as oncotargets
}

\author{
Yang Jiao ${ }^{1, *}$, Yirong Wang ${ }^{2, *}$, Shanchun Guo ${ }^{3}$ and Guangdi Wang ${ }^{3}$ \\ ${ }^{1}$ Department of Stomatology, PLA Army General Hospital, Beijing, P.R. China \\ ${ }^{2}$ State Key Laboratory of Military Stomatology \& National Clinical Research Center for Oral Diseases \& Shaanxi Key Laboratory \\ of Oral Diseases, Department of Operative Dentistry and Endodontics, School of Stomatology, The Fourth Military Medical \\ University, Xi'an, P.R. China \\ ${ }^{3}$ RCMI Cancer Research Center and Department of Chemistry, Xavier University of Louisiana, New Orleans, LA, USA \\ * These authors have contributed equally to this work \\ Correspondence to: Shanchun Guo, email: sguo@xula.edu \\ Guangdi Wang, email: gwang@xula.edu
}

Keywords: glutathione peroxidases, oxidative stress, reactive oxygen species, carcinogenesis, drug target

Received: November 04,2016 Accepted: June 20,2017 Published: August 16, 2017

Copyright: Jiao et al. This is an open-access article distributed under the terms of the Creative Commons Attribution License 3.0 (CC BY 3.0), which permits unrestricted use, distribution, and reproduction in any medium, provided the original author and source are credited.

\section{ABSTRACT}

Oxidative stress is a disturbance in the equilibrium among free radicals, reactive oxygen species, and endogenous antioxidant defense mechanisms. Oxidative stress is a result of imbalance between the production of reactive oxygen and the biological system's ability to detoxify the reactive intermediates or to repair the resulting damage. Mounting evidence has implicated oxidative stress in various physiological and pathological processes, including DNA damage, proliferation, cell adhesion, and survival of cancer cells. Glutathione peroxidases (GPXS) (EC 1.11.1.9) are an enzyme family with peroxidase activity whose main biological roles are to protect organisms from oxidative damage by reducing lipid hydroperoxides as well as free hydrogen peroxide. Currently, 8 sub-members of GPxs have been identified in humans, all capable of reducing $\mathrm{H}_{2} \mathrm{O}_{2}$ and soluble fatty acid hydroperoxides. A large number of publications has demonstrated that GPxs have significant roles in different stages of carcinogenesis. In this review, we will update recent progress in the study of the roles of GPxs in cancer. Better mechanistic understanding of GPxs will potentially contribute to the development and advancement of improved cancer treatment models.

\section{INTRODUCTION}

Oxidative stress is essentially an imbalance among reactive oxygen species (ROS), free radicals (FR), and endogenous antioxidant defense mechanisms in the cell. Cellular molecules and components will ultimately lose cells viability by severe oxidative damage [1-2].

Oxidative stress is involved in various physiological processes, including cell adhesion, proliferation, DNA damage, and survival. Oxidative stress is also involved in a large number of pathological states, such as Alzheimer's disease [3-5], Parkinson's disease [6-7], atherosclerosis [8-9], heart failure [10-11], fragile $X$ syndrome [12], myocardial infarction [13], Sickle cell disease [14], hepatic encephalopathy [15-16], as well as carcinogenesis [17-20]. Glutathione peroxidases (GPxs) is an enzyme family which has the ability to reduce free hydrogen peroxide to water and reduce lipid hydroperoxides to their corresponding alcohols and its main biological roles are to protect organisms from oxidative stress damage [2124]. GPxs include five members and have been found in different tissues of the body and cell fractions. As expected, GPxs, a major defender against oxidative stress were also reported to be involved in Parkinson's disease [25-27], Alzheimer's disease [28-30], atherosclerosis [3132], myocardial infarction [33-34], heart failure [35-36], Sickle cell disease [37], as well as carcinogenesis [24, 38$39]$. In this review we analyzed the role and function of GPxs in mammalian cells, in the regulation of stem cells and cancer stem cells (CSC), discussed the GPxs-mediated signaling pathways and their potential as biomarkers and drug targets. Additionally, we discussed molecular mechanisms of GPxs in CSC, carcinogenesis, as well as its crosstalk with other signaling pathways. 


\section{EXPRESSION AND FUNCTION OF GPXS IN MAMMALIAN CELLS}

GPxs in vertebrates are comprised of 8 submembers, i.e. GPx 1-8. The molecular mass of the active purified mammalian GPx1, a tetramer of identical subunits of $\sim 22-23 \mathrm{kDa}$, has been estimated to be between 83 and $95 \mathrm{kDa}$ [40-42]. GPx1 is ubiquitously expressed and predominantly found in the cytosol [43] and mitochondria [44]. Recently, exosome-derived GPx1 was also found to be required for the recovery of hepatic oxidant injury [45]. Different locations of the GPx1 may correspond to different functions, i.e. GPx1 in cytosol may scavenge hydrophilic peroxide species such as $\mathrm{H}_{2} \mathrm{O}_{2}$ [43], whereas in mitochondria it may protect mitochondrial DNA from oxidative damage [44, 46]. GPx1 is considered as a major antioxidant enzyme within the GPx family, although GPx1-/- mice apparently were healthy, fertile and showed no increased sensitivity to hyperoxia and could compensate for mild oxidative stress [47].

GPx2 is detected in the gastrointestinal system of mammals and also expressed in human livers [48-49]. Its expression pattern suggests that major function of GPx2 is against ROS derived from the gut. GPx 2 knockout mice do not develop an aberrant phenotype before birth, but GPx2 gene is able to make up for the lack of GPx1 gene expression in the ileum epithelium [50] .

GPx3, mainly expressed in the proximal tubuli of the kidney, is a secreted plasma protein and was found in most extracellular fluids $[43,51]$. GPx3-/- mice show no abnormal phenotype throughout their life times, and GPx3 is not involved in selenium metabolism [52]. However, GPx3 may have glutathione peroxidase activity in the cortical peritubular space, since the specific binding of a large pool of GPx3 is seen in the basement membranes in the kidney cortex [52].

Three distinct GPx4 isoforms with different subcellular localizations are detected in mouse and rat: mitochondrial GPx4 (mGPx4), cytosolic GPx4, and nuclear GPx4 (nGPx4) [53]. Cytosolic GPx4 is implicated for cell survival and embryonic development, while nGPx4 and mGPx4 have been essential in male fertility and spermatogenesis [53]. The key features of GPx4 function are its dual anti-oxidative and anti-apoptotic activities [54]. In developing embryos GPx4 expression correlates with areas of reduced apoptosis in developing limbs [55]. In contrast to GPx1-3, all GPx4 knockout strategies fail to reproduce viable homozygous offspring [56-57].

GPx 5 , the closest homologue to GPx3, is detected in the epididymis of reproductive tract in the mammalian male, and is androgen-regulated [58]. While the kinetics and substrate specificities of GPx5 are not fully understood, the function related to the maintenance of sperm DNA integrity [59]. Thus, GPx5 might be a potent antioxidant scavenger that protects spermatozoa from oxidative injuries that can potentially compromise their integrity and embryo viability [59].

GPx6, as a putative odorant-binding and metabolizing enzyme, was identified by in silico analysis [60]. Its detection appears to be restricted to the embryos and the Bowman's glands [61]. Since GPx6 has not been purified, the knowledge on GPx6 is very limited.

GPx 7 with a cysteine instead of Sec in the catalytic center is a cytoplasmic protein with molecular mass of approximately $22 \mathrm{kDa}$ [62]. GPx7 has little glutathione peroxidase activity in vitro [62] and is detected in the lumen of the endoplasmic reticulum [63]. Recently, GPx7 was identified as a stress sensor that transmits oxidative stress signals and it is critical for releasing excessive ER stress by increasing GRP78 chaperone activity [64].

GPx8 as a novel member belonging to the GPx family, has been identified in a phylogenetic analysis in amphibia and mammalia [65]. GPx8 is a membrane protein, lung-abundant enzyme and is detected in endoplasmic reticulum $[63,66]$. However, little is known about its role.

As described above, the functions of most of these proteins are not completely known, but they may all be capable of reducing hydroperoxides: $\mathrm{ROOH}$ $+2 \mathrm{GSH} \rightarrow \mathrm{ROH}+\mathrm{H}_{2} \mathrm{O}+\mathrm{GSSG}$. Thus, a common function of GPxs should be related to the metabolism of hydroperoxides.

\section{GPXS IN THE REGULATION OF STEM CELLS}

Stem cell (SC) research has obtained increasing attention in the past decade due to their invaluable clinical potentials to cure genetic disorders, degenerative diseases, and even cancers. SCs present in all multicellular organisms, can self-renew to produce more SCs and can divide and differentiate into diverse specialized cell types [67]. Although considerable studies have been performed in elucidating the molecular mechanisms in the regulation of self-renewal and differentiation of all kinds of SCs, relatively little effort has been made in investigating the metabolic aspects of SCs [67-68].

Since both embryonic SCs and adult SCs are sources of different types of mature cells, SCs must need specific protection from the long-term effects of oxidative damage and ROS. The intersection of SC function and ROS was proven from the study of mice that lack the function of the gene ataxia telangiectasia mutated (Atm). Most Atm knockout mice die at early, whereas a small percentage of mice survive [69]. Further analysis showed that Atm-/- hematopoietic SCs (HSC) had a severe defect in self-renewal and a marked increase in ROS levels [69]. Analysis of HSCs from conditional knockout of FoxO1, FoxO3, and FoxO4 mice showed an increase in ROS levels and a decline in long-term repopulating activity [70]. In a recent study, Prdm16 deficiency was proven to 
lead to changes in the levels of ROS, depletion of SCs, altered cell-cycle distribution in the haematopoietic and nervous systems and an increase in ROS levels [71]. Prdm16 is a transcription factor that Prdm16 binds to the Hgf promoter, and Hgf expression declined in the absence of Prdm 16 [72-74]. In neural SCs, Prdm16 binds to the Hgf promoter, and Hgf expression declined in the absence of Prdm16 [71]. Thus, Prdm16, promotes SC maintenance and self-renewal in multiple tissues, partly by modulating oxidative stress. All these findings involving Atm, FoxO, as well as Prdm16 indicate that there is a strong correlation between the maintenance of SC function and ROS homeostasis.

In recent years, the role of GPxs in the regulation of SCs is finally being recognized. GPx1 is an important antioxidant enzyme in preventing the harmful accumulation of intracellular hydrogen peroxide. Although GPx1-/- mice were apparently healthy [47], GPx1 was still considered to be the most important member of GPx family in modulating redox-mediated responses and cellular oxidant stress, as well as in the regulation of SCs $[21,75]$. Localization of GPx2 in the intestinal crypt epithelium points to a specific function of this particular GPx in the gastrointestinal SC regulation. Loss of GPx2 led to an increase in apoptotic cells at colonic crypt bases, an area critical for the self-renewal of the intestinal epithelium [76]. These results indicate a role for GPx2 in regulating intestinal mucosal SC homeostasis.
Recently, GPx3 was demonstrated that it is essential for human skeletal muscle precursor cell survival [77]. In an early report, in normal HSCs without function of GPx3 were much less competitive in vivo than in control cells. While HSCs overexpressing GPx3 with overexpression of the self-renewal genes Prdm16 or Hoxb4 boosted GPx3 expression were significantly more competitive than control cells [78]. As mentioned above, GPx4 is essential for embryonic SC development andsurvival, especially in spermatogenesis and male fertility [53], and GPx5 may also have a role in the mammalian male $\mathrm{SC}$ regulation [58]. So far, there has been no report about the role of GPx6, 7 and 8 in SC regulation.

\section{GPXS IN SEVERAL TYPES OF TUMOR}

Changes in GPx levels in several types of tumor have been reported. However, it remains unknown which of the GPx level changes are causative factors in caner progression. The role of GPx1 in tumor and its potential future therapies has been recently reviewed and discussed $[21,61]$. GPx1 was reported to prevent oxidative DNA mutations, thus GPx1 may prevent tumorigenesis [79]. Overexpressed GPx1 reduced growth of tumors indicates that it has a role of the protective effect in tumorigenesis [80]. GPx1 polymorphism in a number of malignancy subjects showed that it may be an important

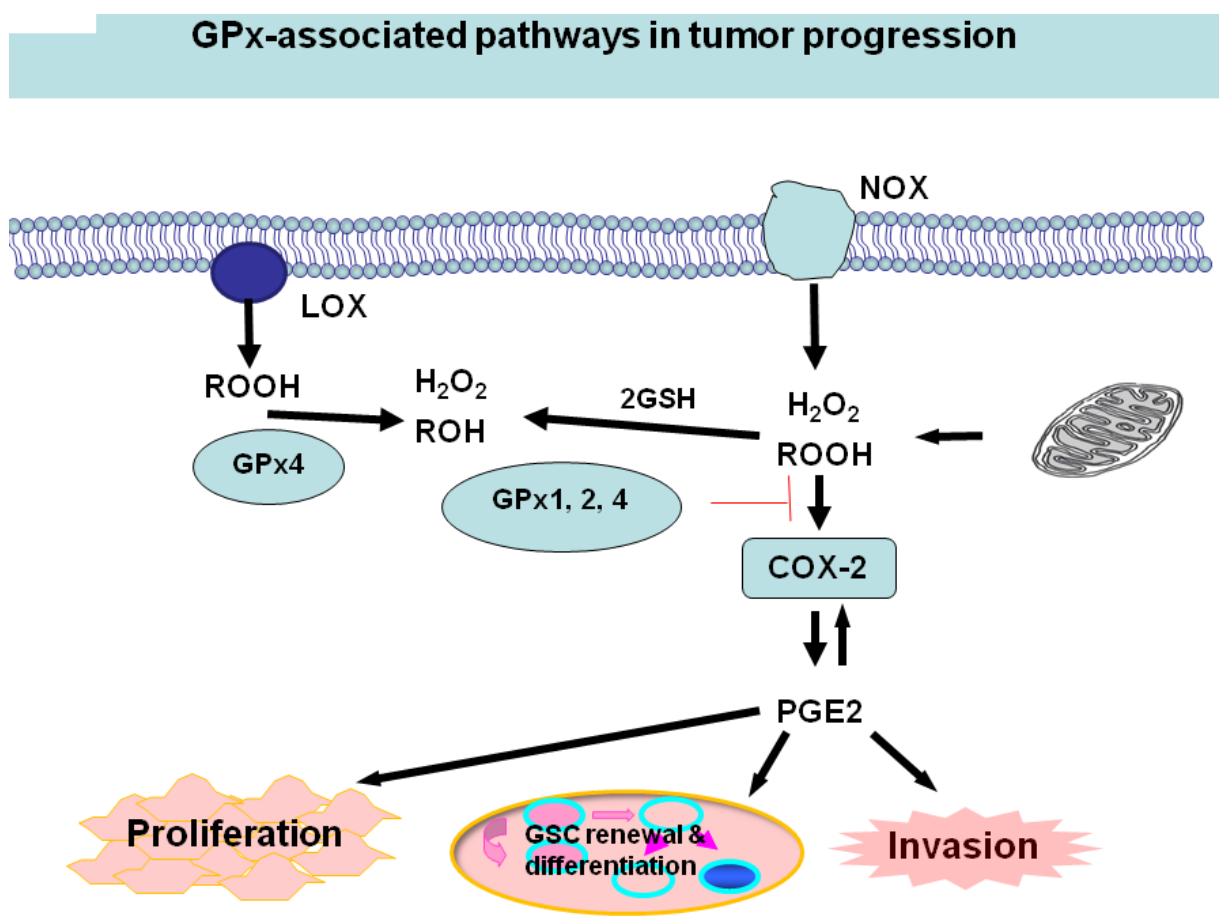

Figure 1: GPxs and COX/LOX activity. Mitochondria and NADPH oxidases (NOX) are intracellular sources of $\mathrm{H}_{2} \mathrm{O}_{2}$ or other hydroperoxides (ROOH). $\mathrm{H}_{2} \mathrm{O}_{2}$ and $\mathrm{ROOH}$ are reduced by all GPx1, 2, and 4 and also by GPx3. Hydroperoxides activate COX-2, which in principle, is inhibited by all GPxs, preferentially; however, by GPx4. COX-2 forms PGE2, which in an autocrine loop can induce the expression of COX-2 to further increase PGE2 production to promote cancer cell proliferation, invasion, self-renewal, and differentiation of CSCs. 
factor modifying oxidative stress response [81-86]. The dual role of GPx2 in tumorigenesis has been reviewed recently [38, 61]. Overexpression of GPx2 was observed in several tumors including colorectal cancer [87-88], Barrett's esophagus carcinoma [89-90], and lung cancer [91], indicating that GPx2 may be an oncogene. However, GPx2 was also observed to be down-regulated in prostatic intraepithelial neoplasia [91], indicating GPx2 may play a more complex role in tumorigenesis. GPx3 is considered to be a novel tumor suppressor, since hypermethylation of the GPx3 was detected in tumor samples from patients with Barrett's esophagus [92-94], endometrial [95] and prostate cancer [96], and down-regulation was generally correlated with worse prognosis. Since changes in GPx3 hypermethylation are reversible, drug treatment through demethylation may be a useful strategy to delay carcinogenesis and progression. In fact, the expression of GPX3 mRNA and protein was restored in several types of cancer cells after treatment with 5-aza-2'-deoxycytidine and [94, 97-98]. This method may bring new direction and potential for cancer treatment through gene-targeted therapy. GPx4 is also considered to be a tumor suppressor, since it was down-regulated in pancreatic [80] and breast cancer [99]. In addition, GPx4 overexpression reduced fibrosarcoma cell growth [100]. So far, there is no report on the role of GPx5, 6, 7 and 8 in tumorigenesis.

\section{GPXS IN CANCER STEM CELLS}

Cancer cells are believed to originate from a small subpopulation of cells that have a high capacity of aberrantly self-renewal and differentiation, namely tumorinitiating cells or cancer stem cells (CSCs) [101-102]. CSCs have characteristics associated with normal stem cells, specifically the ability to cause the heterogeneous lineages or cell types [103-104]. Although their role and existence remain controversial, the reports of CSCs in mouse tumors also support this concept [105-106]. Unlike SCs, which have the differentiation process leading to specialized progenies with no proliferative potential, CSCs give rise to progenies that do not undergo terminal differentiation but instead exhibit uncontrolled proliferation. There are also differences in cell-cycle properties, mode of division, replicative potential, and DNA damage repairs. Through deregulation of the selfrenewal process, CSCs initiate and drive carcinogenesis and contribute cellular heterogeneity [107]. Thus, CSCs may be a risk biomarker for carcinogenesis [108]. Previous studies also demonstrated that CSCs in solid tumors that are responsible for tumor initiation, progression, metastasis and drug resistance [109-110].

In comparison with cancer cells or SCs, relatively little is known about the ROS in CSCs. Similar to SCs, CSCs also contain lower intracellular ROS contents due to the increased production of free radical scavenging systems [111-112]. In addition, the unchecked ROS production may play a role in the leukemic initiation [113114]. CSCs might have a high antioxidant capacity to keep cellular ROS at a moderate level. Breast CSCs exhibit an enhanced ROS defense system and lower levels of basal and radiation-induced ROS which may be associated with tumorigenicity and resistance to radiation [111]. Recently, CD13/Aminopeptidase N, a scavenger enzyme in the ROS metabolic pathway [115-116], was demonstrated to play a role in supporting the survival of CSCs and that there is an EMT-associated reduction in ROS elevation [117]. CSCs display an EMT phenotype and are resistant to current therapies. More recently, Dong et al showed that these phenotypes are stimulated by a metabolic switch to glucose metabolism, resulting in decreased ROS production in basal-like breast cancer [118].

Mitochondria and NADPH oxidases (NOX) are intracellular sources of $\mathrm{H}_{2} \mathrm{O}_{2}$ or other hydroperoxides ( $\mathrm{ROOH}$ ). A number of studies have established that $\mathrm{H}_{2} \mathrm{O}_{2}$ and/or $\mathrm{ROOH}$ are able to activate cyclooxygenase- 2 (COX-2), one of the cyclooxygenases that catalyze a critical step in the formation of proinflammatory prostaglandins, e.g., PGE2 [24, 119-120]. COX-2 is overexpressed in cancer tissues [121-122], as well as in several kinds of CSCs [123-125]. PGE2, the main product of the COX-2 cascade play a role in the acute inflammatory response [126] and in tumor cell proliferation and invasion [127]. PGE2 enhances tumor cell proliferation and inhibits apoptosis by the activation of pro-survival pathways such as the PI3K/Akt or the Ras-MAPK/ERK pathways. PGE2 also supports cancer cell migration, invasion [126-127], and angiogenesis [128-129]. Moreover, PGE2 induces CSCs through the Wnt pathway [130-131].

An imbalance or dysregulation of ROS levels may generate cells with abnormal growth, therefore potentially tumorigenic. Thus, a precise balance between processes generating ROS and those decomposing ROS is critical for tumor development including CSC self-renewal and differentiation. One tier of the cellular protective system against ROS constitutes the GPx family. Due to the significant role GPxs play in modulating redox-mediated responses and cellular oxidant stress, certain members of GPx may also play a critical role in CSC self-renewal and differentiation [61, 132-133]. Glioma stem cell lines expressing active GPx1 might decrease ROS level in Glioma CSCs and resist ROS/RNS-mediated cell death, thus creates a carcinoma stem cell niche [134]. Herault et al also reported that the expression of ROS scavenger, GPx3 associates with the frequency of leukemia stem cells (LSCs) in induced leukemias [78]. In addition, GPxs can potentially directly decrease $\mathrm{H}_{2} \mathrm{O}_{2}$ and/or ROOH level, then inactivate COX-2 and PEG2 and finally modulate CSCs (Figure 1). Recently, the Weinberg's group showed that tumor cells strongly induced the COX-2/microsomal prostaglandin-E synthase-1 (mPGES-1)/PGE2 axis in MSCs [135]. GPxs, such as GPx1 also significantly impact human endothelial cell activation and proinflammatory 
cytokine-induced redox signaling [136-138], while endothelial cell activation is considered to be able to create a niche that helps promote self-renewal of CSCs [139140]. Therefore, GPxs can potentially modulate CSCs through multiple pathways.

\section{CONCLUSIONS}

A lot of knowledge has been learned about the GPx family in redox biology and cancer biology since their discoveries as crucial antioxidant enzymes that inactivate peroxides. GPxs participate in balancing the $\mathrm{H}_{2} \mathrm{O}_{2}$ homeostasis in signaling cascades and in tumorigenesis. GPx1, GPx2, GPx3 and 4 are also implicated in selfrenewal and differentiation of stem cells and CSCs through multiple pathways. The current challenge is to unravel how the different GPx members can exert highly specific biological functions. The functions of some members of GPx, such as GPx6, 7 and 8 are still not known and require further research.

\section{CONFLICTS OF INTEREST}

The authors have no conflicts of interest to declare.

\section{REFERENCES}

1. Sinha K, Das J, Pal PB, Sil PC. Oxidative stress: the mitochondria-dependent and mitochondria-independent pathways of apoptosis. Arch Toxicol. 2013; 30: 30.

2. Devasagayam TP, Tilak JC, Boloor KK, Sane KS, Ghaskadbi SS, Lele RD. Free radicals and antioxidants in human health: current status and future prospects. J Assoc Physicians India. 2004; 52: 794-804.

3. Greenough MA, Camakaris J, Bush AI. Metal dyshomeostasis and oxidative stress in Alzheimer's disease. Neurochem Int. 2013; 62: 540-55.

4. Eskici G, Axelsen PH. Copper and oxidative stress in the pathogenesis of Alzheimer's disease. Biochemistry. 2012; 51: 6289-311.

5. Massaad CA. Neuronal and vascular oxidative stress in Alzheimer's disease. Curr Neuropharmacol. 2011; 9: $662-$ 73.

6. Ciccone S, Maiani E, Bellusci G, Diederich M, Gonfloni S. Parkinson's disease: a complex interplay of mitochondrial DNA alterations and oxidative stress. Int J Mol Sci. 2013; 14: $2388-409$.

7. Janda E, Isidoro C, Carresi C, Mollace V. Defective autophagy in Parkinson's disease: role of oxidative stress. Mol Neurobiol. 2012; 46: 639-61.

8. Peluso I, Morabito G, Urban L, Ioannone F, Serafini M. Oxidative stress in atherosclerosis development: the central role of LDL and oxidative burst. Endocr Metab Immune Disord Drug Targets. 2012; 12: 351-60.
9. Vogiatzi G, Tousoulis D, Stefanadis C. The role of oxidative stress in atherosclerosis. Hellenic J Cardiol. 2009; 50: 4029.

10. Ahmed Z, Tang WH. Pharmacologic strategies to target oxidative stress in heart failure. Curr Heart Fail Rep. 2012; 9: $14-22$

11. Tsutsui H, Kinugawa S, Matsushima S. Oxidative stress and mitochondrial DNA damage in heart failure. Circ J. 2008; 72 Suppl A: A31-7.

12. el Bekay R, Romero-Zerbo Y, Decara J, Sanchez-Salido L, Del Arco-Herrera I, Rodriguez-de Fonseca F, de DiegoOtero Y. Enhanced markers of oxidative stress, altered antioxidants and NADPH-oxidase activation in brains from Fragile X mental retardation 1-deficient mice, a pathological model for Fragile X syndrome. Eur J Neurosci. 2007; 26: 3169-80.

13. Di Filippo C, Cuzzocrea S, Rossi F, Marfella R, D’Amico M. Oxidative stress as the leading cause of acute myocardial infarction in diabetics. Cardiovasc Drug Rev. 2006; 24: 7787.

14. Nur E, Biemond BJ, Otten HM, Brandjes DP, Schnog JJ. Oxidative stress in sickle cell disease; pathophysiology and potential implications for disease management. Am J Hematol. 2011; 86: 484-9.

15. Seyan AS, Hughes RD, Shawcross DL. Changing face of hepatic encephalopathy: role of inflammation and oxidative stress. World J Gastroenterol. 2010; 16: 3347-57.

16. Schliess F, Gorg B, Haussinger D. Pathogenetic interplay between osmotic and oxidative stress: the hepatic encephalopathy paradigm. Biol Chem. 2006; 387: 1363-70.

17. Sohal RS, Weindruch R. Oxidative stress, caloric restriction, and aging. Science. 1996; 273: 59-63.

18. Wang L, Chen F, Zhang Z, Chen G, Luo J, Shi X. Cancer stem cells in the mechanism of metal carcinogenesis. J Environ Pathol Toxicol Oncol. 2012; 31: 245-63.

19. Ziech D, Franco R, Pappa A, Panayiotidis MI. Reactive oxygen species (ROS)--induced genetic and epigenetic alterations in human carcinogenesis. Mutat Res. 2011; 711: 167-73.

20. Kryston TB, Georgiev AB, Pissis P, Georgakilas AG. Role of oxidative stress and DNA damage in human carcinogenesis. Mutat Res. 2011; 711: 193-201.

21. Lubos E, Loscalzo J, Handy DE. Glutathione peroxidase-1 in health and disease: from molecular mechanisms to therapeutic opportunities. Antioxid Redox Signal. 2011; 15: 1957-97.

22. Battin EE, Brumaghim JL. Antioxidant activity of sulfur and selenium: a review of reactive oxygen species scavenging, glutathione peroxidase, and metal-binding antioxidant mechanisms. Cell Biochem Biophys. 2009; 55: $1-23$.

23. Toppo S, Flohe L, Ursini F, Vanin S, Maiorino M. Catalytic mechanisms and specificities of glutathione peroxidases: variations of a basic scheme. Biochim Biophys Acta. 2009; 
1790: $1486-500$.

24. Brigelius-Flohe R, Kipp A. Glutathione peroxidases in different stages of carcinogenesis. Biochim Biophys Acta. 2009; 1790: 1555-68.

25. Kish SJ, Morito C, Hornykiewicz O. Glutathione peroxidase activity in Parkinson's disease brain. Neurosci Lett. 1985; 58: 343-6.

26. Johannsen P, Velander G, Mai J, Thorling EB, Dupont E. Glutathione peroxidase in early and advanced Parkinson's disease. J Neurol Neurosurg Psychiatry. 1991; 54: 679-82.

27. Thiruchelvam M, Prokopenko O, Cory-Slechta DA, Buckley B, Mirochnitchenko O. Overexpression of superoxide dismutase or glutathione peroxidase protects against the paraquat + maneb-induced Parkinson disease phenotype. J Biol Chem. 2005; 280: 22530-9.

28. Yoo MH, Gu X, Xu XM, Kim JY, Carlson BA, Patterson AD, Cai H, Gladyshev VN, Hatfield DL. Delineating the role of glutathione peroxidase 4 in protecting cells against lipid hydroperoxide damage and in Alzheimer's disease. Antioxid Redox Signal. 2010; 12: 819-27.

29. Ceballos-Picot I, Merad-Boudia M, Nicole A, Thevenin M, Hellier G, Legrain S, Berr C. Peripheral antioxidant enzyme activities and selenium in elderly subjects and in dementia of Alzheimer's type--place of the extracellular glutathione peroxidase. Free Radic Biol Med. 1996; 20: 579-87.

30. Paz-y-Mino C, Carrera C, Lopez-Cortes A, Munoz MJ, Cumbal N, Castro B, Cabrera A, Sanchez ME. Genetic polymorphisms in apolipoprotein $\mathrm{E}$ and glutathione peroxidase 1 genes in the Ecuadorian population affected with Alzheimer's disease. Am J Med Sci. 2010; 340: 373-7.

31. Lewis P, Stefanovic N, Pete J, Calkin AC, Giunti S, Thallas-Bonke V, Jandeleit-Dahm KA, Allen TJ, Kola I, Cooper ME, de Haan JB. Lack of the antioxidant enzyme glutathione peroxidase-1 accelerates atherosclerosis in diabetic apolipoprotein E-deficient mice. Circulation. 2007; 115: 2178-87.

32. Lin MS, Hsu HC, Lin LC, Li HY, Lee BC, Lee YT, Chen MF. Higher glutathione peroxidase expression in thoracic aorta as a protective factor against oxidative stress and atherosclerosis in rabbits. Cardiology. 2007; 108: 381-6.

33. Yoshida T, Watanabe M, Engelman DT, Engelman RM, Schley JA, Maulik N, Ho YS, Oberley TD, Das DK. Transgenic mice overexpressing glutathione peroxidase are resistant to myocardial ischemia reperfusion injury. J Mol Cell Cardiol. 1996; 28: 1759-67.

34. Cheng ML, Chen CM, Ho HY, Li JM, Chiu DT. Effect of acute myocardial infarction on erythrocytic glutathione peroxidase 1 activity and plasma vitamin e levels. Am J Cardiol. 2009; 103: 471-5.

35. Shiomi T, Tsutsui $H$, Matsusaka $H$, Murakami $K$, Hayashidani S, Ikeuchi M, Wen J, Kubota T, Utsumi H, Takeshita A. Overexpression of glutathione peroxidase prevents left ventricular remodeling and failure after myocardial infarction in mice. Circulation. 2004; 109: 544-
9.

36. Dabkowski ER, Williamson CL, Hollander JM. Mitochondria-specific transgenic overexpression of phospholipid hydroperoxide glutathione peroxidase (GPx4) attenuates ischemia/reperfusion-associated cardiac dysfunction. Free Radic Biol Med. 2008; 45: 855-65.

37. Natta CL, Chen LC, Chow CK. Selenium and glutathione peroxidase levels in sickle cell anemia. Acta Haematol. 1990; 83: 130-2.

38. Brigelius-Flohe R, Kipp AP. Physiological functions of GPx2 and its role in inflammation-triggered carcinogenesis. Ann N Y Acad Sci. 2012; 1259: 19-25.

39. Zhuo P, Diamond AM. Molecular mechanisms by which selenoproteins affect cancer risk and progression. Biochim Biophys Acta. 2009; 1790: 1546-54.

40. Awasthi YC, Beutler E, Srivastava SK. Purification and properties of human erythrocyte glutathione peroxidase. $\mathrm{J}$ Biol Chem. 1975; 250: 5144-9.

41. Miwa T, Adachi T, Ito Y, Hirano K, Sugiura M. Purification and properties of glutathione peroxidase from human liver. Chem Pharm Bull (Tokyo). 1983; 31: 179-85.

42. Oh SH, Ganther HE, Hoekstra WG. Selenium as a component of glutathione periodase isolated from ovine erythrocytes. Biochemistry. 1974; 13: 1825-9.

43. Brigelius-Flohe R. Tissue-specific functions of individual glutathione peroxidases. Free Radic Biol Med. 1999; 27 : 951-65.

44. Legault J, Carrier C, Petrov P, Renard P, Remacle J, Mirault ME. Mitochondrial GPx 1 decreases induced but not basal oxidative damage to mtDNA in T47D cells. Biochem Biophys Res Commun. 2000; 272: 416-22.

45. Yan Y, Jiang W, Tan Y, Zou S, Zhang H, Mao F, Gong A, Qian H, Xu W. hucMSC Exosome-Derived GPX1 Is Required for the Recovery of Hepatic Oxidant Injury. Mol Ther. 2017; 25: 465-79.

46. Kienhofer J, Haussler DJ, Ruckelshausen F, Muessig E, Weber K, Pimentel D, Ullrich V, Burkle A, Bachschmid MM. Association of mitochondrial antioxidant enzymes with mitochondrial DNA as integral nucleoid constituents. FASEB J. 2009; 23: 2034-44.

47. Ho YS, Magnenat JL, Bronson RT, Cao J, Gargano M, Sugawara M, Funk CD. Mice deficient in cellular glutathione peroxidase develop normally and show no increased sensitivity to hyperoxia. J Biol Chem. 1997; 272: 16644-51.

48. Chu FF, Doroshow JH, Esworthy RS. Expression, characterization, and tissue distribution of a new cellular selenium-dependent glutathione peroxidase, GSHPx-GI. J Biol Chem. 1993; 268: 2571-6.

49. Dreher I, Schmutzler C, Jakob F, Kohrle J. Expression of selenoproteins in various rat and human tissues and cell lines. J Trace Elem Med Biol. 1997; 11: 83-91.

50. Esworthy RS, Mann JR, Sam M, Chu FF. Low glutathione peroxidase activity in Gpx1 knockout mice protects jejunum 
crypts from gamma-irradiation damage. Am J Physiol Gastrointest Liver Physiol. 2000; 279: G426-36.

51. Avissar N, Ornt DB, Yagil Y, Horowitz S, Watkins RH, Kerl EA, Takahashi K, Palmer IS, Cohen HJ. Human kidney proximal tubules are the main source of plasma glutathione peroxidase. Am J Physiol. 1994; 266: C367-75.

52. Olson GE, Whitin JC, Hill KE, Winfrey VP, Motley AK, Austin LM, Deal J, Cohen HJ, Burk RF. Extracellular glutathione peroxidase (Gpx3) binds specifically to basement membranes of mouse renal cortex tubule cells. Am J Physiol Renal Physiol. 2010; 298: F1244-53.

53. Schneider M, Forster H, Boersma A, Seiler A, Wehnes H, Sinowatz F, Neumuller C, Deutsch MJ, Walch A, Hrabe de Angelis M, Wurst W, Ursini F, Roveri A, et al. Mitochondrial glutathione peroxidase 4 disruption causes male infertility. FASEB J. 2009; 23: 3233-42.

54. Savaskan NE, Ufer C, Kuhn H, Borchert A. Molecular biology of glutathione peroxidase 4: from genomic structure to developmental expression and neural function. Biol Chem. 2007; 388: 1007-17.

55. Schnabel D, Salas-Vidal E, Narvaez V, Sanchez-Carbente Mdel R, Hernandez-Garcia D, Cuervo R, Covarrubias L. Expression and regulation of antioxidant enzymes in the developing limb support a function of ROS in interdigital cell death. Dev Biol. 2006; 291: 291-9.

56. Imai H, Hirao F, Sakamoto T, Sekine K, Mizukura Y, Saito M, Kitamoto T, Hayasaka M, Hanaoka K, Nakagawa Y. Early embryonic lethality caused by targeted disruption of the mouse PHGPx gene. Biochem Biophys Res Commun. 2003; 305: 278-86.

57. Yant LJ, Ran Q, Rao L, Van Remmen H, Shibatani T, Belter JG, Motta L, Richardson A, Prolla TA. The selenoprotein GPX4 is essential for mouse development and protects from radiation and oxidative damage insults. Free Radic Biol Med. 2003; 34: 496-502.

58. Rejraji H, Vernet P, Drevet JR. GPX5 is present in the mouse caput and cauda epididymidis lumen at three different locations. Mol Reprod Dev. 2002; 63: 96-103.

59. Chabory E, Damon C, Lenoir A, Kauselmann G, Kern H, Zevnik B, Garrel C, Saez F, Cadet R, Henry-Berger J, Schoor M, Gottwald U, Habenicht U, et al. Epididymis seleno-independent glutathione peroxidase 5 maintains sperm DNA integrity in mice. J Clin Invest. 2009; 119: 2074-85.

60. Dear TN, Campbell K, Rabbitts TH. Molecular cloning of putative odorant-binding and odorant-metabolizing proteins. Biochemistry. 1991; 30: 10376-82.

61. Brigelius-Flohe R, Maiorino M. Glutathione peroxidases. Biochim Biophys Acta. 2013; 1830: 3289-303.

62. Utomo A, Jiang X, Furuta S, Yun J, Levin DS, Wang YC, Desai KV, Green JE, Chen PL, Lee WH. Identification of a novel putative non-selenocysteine containing phospholipid hydroperoxide glutathione peroxidase (NPGPx) essential for alleviating oxidative stress generated from polyunsaturated fatty acids in breast cancer cells. J Biol Chem. 2004; 279: 43522-9.

63. Nguyen VD, Saaranen MJ, Karala AR, Lappi AK, Wang L, Raykhel IB, Alanen HI, Salo KE, Wang CC, Ruddock LW. Two endoplasmic reticulum PDI peroxidases increase the efficiency of the use of peroxide during disulfide bond formation. J Mol Biol. 2011; 406: 503-15.

64. Wei PC, Hsieh YH, Su MI, Jiang X, Hsu PH, Lo WT, Weng JY, Jeng YM, Wang JM, Chen PL, Chang YC, Lee KF, Tsai MD, et al. Loss of the oxidative stress sensor NPGPx compromises GRP78 chaperone activity and induces systemic disease. Mol Cell. 2012; 48: 747-59.

65. Toppo S, Vanin S, Bosello V, Tosatto SC. Evolutionary and structural insights into the multifaceted glutathione peroxidase (Gpx) superfamily. Antioxid Redox Signal. 2008; 10: 1501-14.

66. Yamada Y, Limmon GV, Zheng D, Li N, Li L, Yin L, Chow VT, Chen J, Engelward BP. Major shifts in the spatio-temporal distribution of lung antioxidant enzymes during influenza pneumonia. Plos one. 2012; 7: e31494.

67. Vacanti NM, Metallo CM. Exploring metabolic pathways that contribute to the stem cell phenotype. Biochim Biophys Acta. 2013; 1830: 2361-9.

68. Ramm Sander P, Hau P, Koch S, Schutze K, Bogdahn U, Kalbitzer HR, Aigner L. Stem cell metabolic and spectroscopic profiling. Trends Biotechnol. 2013; 31: 20413.

69. Ito K, Hirao A, Arai F, Matsuoka S, Takubo K, Hamaguchi I, Nomiyama K, Hosokawa K, Sakurada K, Nakagata N, Ikeda Y, Mak TW, Suda T. Regulation of oxidative stress by ATM is required for self-renewal of haematopoietic stem cells. Nature. 2004; 431: 997-1002.

70. Tothova Z, Kollipara R, Huntly BJ, Lee BH, Castrillon DH, Cullen DE, McDowell EP, Lazo-Kallanian S, Williams IR, Sears C, Armstrong SA, Passegue E, DePinho RA, et al. FoxOs are critical mediators of hematopoietic stem cell resistance to physiologic oxidative stress. Cell. 2007; 128 : 325-39.

71. Chuikov S, Levi BP, Smith ML, Morrison SJ. Prdm16 promotes stem cell maintenance in multiple tissues, partly by regulating oxidative stress. Nat Cell Biol. 2010; 12: 9991006.

72. Aguilo F, Avagyan S, Labar A, Sevilla A, Lee DF, Kumar P, Lemischka IR, Zhou BY, Snoeck HW. Prdm16 is a physiologic regulator of hematopoietic stem cells. Blood. 2011; 117: 5057-66.

73. Horn KH, Warner DR, Pisano M, Greene RM. PRDM16 expression in the developing mouse embryo. Acta Histochem. 2011; 113: 150-5.

74. Kajimura S, Seale P, Kubota K, Lunsford E, Frangioni JV, Gygi SP, Spiegelman BM. Initiation of myoblast to brown fat switch by a PRDM16-C/EBP-beta transcriptional complex. Nature. 2009; 460: 1154-8.

75. De Haan JB, Crack PJ, Flentjar N, Iannello RC, Hertzog 
PJ, Kola I. An imbalance in antioxidant defense affects cellular function: the pathophysiological consequences of a reduction in antioxidant defense in the glutathione peroxidase-1 (Gpx1) knockout mouse. Redox Rep. 2003; 8: 69-79.

76. Florian S, Krehl S, Loewinger M, Kipp A, Banning A, Esworthy S, Chu FF, Brigelius-Flohe R. Loss of GPx2 increases apoptosis, mitosis, and GPx1 expression in the intestine of mice. Free Radic Biol Med. 2010; 49: 1694702 .

77. El Haddad M, Jean E, Turki A, Hugon G, Vernus B, Bonnieu A, Passerieux E, Hamade A, Mercier J, LaoudjChenivesse D, Carnac G. Glutathione peroxidase 3, a new retinoid target gene, is crucial for human skeletal muscle precursor cell survival. J Cell Sci. 2012; 125: 6147-56.

78. Herault O, Hope KJ, Deneault E, Mayotte N, Chagraoui J, Wilhelm BT, Cellot S, Sauvageau M, Andrade-Navarro MA, Hebert J, Sauvageau G. A role for GPx3 in activity of normal and leukemia stem cells. J Exp Med. 2012; 209: 895-901.

79. Baliga MS, Wang H, Zhuo P, Schwartz JL, Diamond AM. Selenium and GPx-1 overexpression protect mammalian cells against UV-induced DNA damage. Biol Trace Elem Res. 2007; 115: 227-42.

80. Liu J, Du J, Zhang Y, Sun W, Smith BJ, Oberley LW, Cullen JJ. Suppression of the malignant phenotype in pancreatic cancer by overexpression of phospholipid hydroperoxide glutathione peroxidase. Hum Gene Ther. 2006; 17: 105-16.

81. Jablonska E, Gromadzinska J, Peplonska B, Fendler W, Reszka E, Krol MB, Wieczorek E, Bukowska A, Gresner P, Galicki M, Zambrano Quispe O, Morawiec Z, Wasowicz W. Lipid peroxidation and glutathione peroxidase activity relationship in breast cancer depends on functional polymorphism of GPX1. BMC Cancer. 2015; 15: 657. doi: 10.1186/s12885-015-1680-4.

82. Parlaktas BS, Atilgan D, Gencten Y, Benli I, Ozyurt H, Uluocak N, Erdemir F. A pilot study of the association of manganese superoxide dismutase and glutathione peroxidase 1 single gene polymorphisms with prostate cancer and serum prostate specific antigen levels. Arch Med Sci. 2015; 11: 994-1000. doi: 10.5114/aoms.2015.54853.

83. Banescu C, Iancu M, Trifa AP, Candea M, Benedek Lazar E, Moldovan VG, Duicu C, Tripon F, Crauciuc A, Dobreanu M. From Six Gene Polymorphisms of the Antioxidant System, Only GPX Pro198Leu and GSTP1 Ile105Val Modulate the Risk of Acute Myeloid Leukemia. Oxid Med Cell Longev. 2016; 2016: 2536705. doi: 10.1155/2016/2536705.

84. Trifa AP, Banescu C, Dima D, Bojan AS, Tevet M, Moldovan VG, Vesa SC, Murat M, Pop IV, Skrypnyk C, Popp RA. Among a panel of polymorphisms in genes related to oxidative stress, CAT-262 C>T, GPX1 Pro198Leu and GSTP1 Ile105Val influence the risk of developing BCRABL negative myeloproliferative neoplasms. Hematology.
2016; 21: 520-5. doi: 10.1080/10245332.2016.1163889.

85. Krhin B, Goricar K, Gazic B, Dolzan V, Besic N. Functional polymorphisms in antioxidant genes in Hurthle cell thyroid neoplasm - an association of GPX1 polymorphism and recurrent Hurthle cell thyroid carcinoma. Radiol Oncol. 2016; 50: 289-96. doi: 10.1515/raon-2016-0031.

86. Hadami K, Ameziane El Hassani R, Ameur A, Dakka N, Abbar M, Al Bouzidi A, Attaleb M, El Mzibri M. Association between GPX1 Pro189Leu polymorphism and the occurrence of bladder cancer in Morocco. Cell Mol Biol (Noisy-le-grand). 2016; 62: 38-43.

87. Al-Taie OH, Uceyler N, Eubner U, Jakob F, Mork H, Scheurlen M, Brigelius-Flohe R, Schottker K, Abel $\mathrm{J}$, Thalheimer A, Katzenberger T, Illert B, Melcher $\mathrm{R}$, et al. Expression profiling and genetic alterations of the selenoproteins GI-GPx and SePP in colorectal carcinogenesis. Nutr Cancer. 2004; 48: 6-14.

88. Chiu ST, Hsieh FJ, Chen SW, Chen CL, Shu HF, Li H. Clinicopathologic correlation of up-regulated genes identified using cDNA microarray and real-time reverse transcription-PCR in human colorectal cancer. Cancer Epidemiol Biomarkers Prev. 2005; 14: 437-43.

89. Mork H, Scheurlen M, Al-Taie O, Zierer A, Kraus M, Schottker K, Jakob F, Kohrle J. Glutathione peroxidase isoforms as part of the local antioxidative defense system in normal and Barrett's esophagus. Int J Cancer. 2003; 105: $300-4$.

90. Serewko MM, Popa C, Dahler AL, Smith L, Strutton GM, Coman W, Dicker AJ, Saunders NA. Alterations in gene expression and activity during squamous cell carcinoma development. Cancer Res. 2002; 62: 3759-65.

91. Woenckhaus M, Klein-Hitpass L, Grepmeier U, Merk J, Pfeifer M, Wild P, Bettstetter M, Wuensch P, Blaszyk H, Hartmann A, Hofstaedter F, Dietmaier W. Smoking and cancer-related gene expression in bronchial epithelium and non-small-cell lung cancers. J Pathol. 2006; 210: 192-204.

92. Lee OJ, Schneider-Stock R, McChesney PA, Kuester D, Roessner A, Vieth M, Moskaluk CA, El-Rifai W. Hypermethylation and loss of expression of glutathione peroxidase-3 in Barrett's tumorigenesis. Neoplasia. 2005; 7: 854-61.

93. Peng DF, Razvi M, Chen H, Washington K, Roessner A, Schneider-Stock R, El-Rifai W. DNA hypermethylation regulates the expression of members of the Mu-class glutathione S-transferases and glutathione peroxidases in Barrett's adenocarcinoma. Gut. 2009; 58: 5-15.

94. He Y, Wang Y, Li P, Zhu S, Wang J, Zhang S. Identification of GPX3 epigenetically silenced by CpG methylation in human esophageal squamous cell carcinoma. Dig Dis Sci. 2011; 56: 681-8. doi: 10.1007/s10620-010-1369-0.

95. Falck E, Karlsson S, Carlsson J, Helenius G, Karlsson M, Klinga-Levan K. Loss of glutathione peroxidase 3 expression is correlated with epigenetic mechanisms in endometrial adenocarcinoma. Cancer Cell Int. 2010; 10: 46. 
96. Yu YP, Yu G, Tseng G, Cieply K, Nelson J, Defrances M, Zarnegar R, Michalopoulos G, Luo JH. Glutathione peroxidase 3, deleted or methylated in prostate cancer, suppresses prostate cancer growth and metastasis. Cancer Res. 2007; 67: 8043-50.

97. Peng DF, Hu TL, Schneider BG, Chen Z, Xu ZK, El-Rifai W. Silencing of glutathione peroxidase 3 through DNA hypermethylation is associated with lymph node metastasis in gastric carcinomas. Plos one. 2012; 7: e46214. doi: 10.1371/journal.pone.0046214.

98. Zhang X, Zheng Z, Yingii S, Kim H, Jin R, Renshu L, Lee DY, Roh MR, Yang S. Downregulation of glutathione peroxidase 3 is associated with lymph node metastasis and prognosis in cervical cancer. Oncol Rep. 2014; 31: 2587-92. doi: 10.3892/or.2014.3152.

99. Cejas P, Garcia-Cabezas MA, Casado E, Belda-Iniesta C, De Castro J, Fresno JA, Sereno M, Barriuso J, Espinosa E, Zamora P, Feliu J, Redondo A, Hardisson DA, et al. Phospholipid hydroperoxide glutathione peroxidase (PHGPx) expression is downregulated in poorly differentiated breast invasive ductal carcinoma. Free Radic Res. 2007; 41: 681-7.

100. Heirman I, Ginneberge D, Brigelius-Flohe R, Hendrickx N, Agostinis P, Brouckaert P, Rottiers P, Grooten J. Blocking tumor cell eicosanoid synthesis by GP x 4 impedes tumor growth and malignancy. Free Radic Biol Med. 2006; 40: 285-94.

101. Nguyen LV, Vanner R, Dirks P, Eaves CJ. Cancer stem cells: an evolving concept. Nat Rev Cancer. 2012; 12: 13343.

102. Guo S, Liu M, Wang G, Torroella-Kouri M, GonzalezPerez RR. Oncogenic role and therapeutic target of leptin signaling in breast cancer and cancer stem cells. Biochim Biophys Acta. 2012; 1825: 207-22. .

103. Beck B, Blanpain C. Unravelling cancer stem cell potential. Nat Rev Cancer. 2013; 13: 727-38.

104. Kreso A, Dick JE. Evolution of the cancer stem cell model. Cell Stem Cell. 2014; 14: 275-91.

105. Parashurama N, Lobo NA, Ito K, Mosley AR, Habte FG, Zabala M, Smith BR, Lam J, Weissman IL, Clarke MF, Gambhir SS. Remodeling of endogenous mammary epithelium by breast cancer stem cells. Stem Cells. 2012; 30: 2114-27.

106. Medema JP. Cancer stem cells: The challenges ahead. Nat Cell Biol. 2013; 15: 338-44.

107. Pang LY, Argyle DJ. Using naturally occurring tumours in dogs and cats to study telomerase and cancer stem cell biology. Biochim Biophys Acta. 2009; 1792: 380-91.

108. Kakarala M, Wicha MS. Implications of the cancer stemcell hypothesis for breast cancer prevention and therapy. J Clin Oncol. 2008; 26: 2813-20.

109. Clarke MF. Self-renewal and solid-tumor stem cells. Biol Blood Marrow Transplant. 2005; 11: 14-6.

110. Clevers H. The cancer stem cell: premises, promises and challenges. Nat Med. 2011; 17: 313-9.

111. Diehn M, Cho RW, Lobo NA, Kalisky T, Dorie MJ, Kulp AN, Qian D, Lam JS, Ailles LE, Wong M, Joshua B, Kaplan MJ, Wapnir I, et al. Association of reactive oxygen species levels and radioresistance in cancer stem cells. Nature. 2009; 458: 780-3.

112. Ye XQ, Li Q, Wang GH, Sun FF, Huang GJ, Bian XW, Yu SC, Qian GS. Mitochondrial and energy metabolism-related properties as novel indicators of lung cancer stem cells. Int J Cancer. 2011; 129: 820-31.

113. Schulze-Bergkamen H, Krammer PH. Apoptosis in cancer-implications for therapy. Semin Oncol. 2004; 31: 90-119.

114. Dell'Eva R, Pfeffer U, Vene R, Anfosso L, Forlani A, Albini A, Efferth T. Inhibition of angiogenesis in vivo and growth of Kaposi's sarcoma xenograft tumors by the antimalarial artesunate. Biochem Pharmacol. 2004; 68: 235966.

115. Haraguchi N, Ishii H, Mimori K, Tanaka F, Ohkuma M, Kim HM, Akita H, Takiuchi D, Hatano H, Nagano H, Barnard GF, Doki Y, Mori M. CD13 is a therapeutic target in human liver cancer stem cells. J Clin Invest. 2010; 120: 3326-39.

116. Christ B, Stock P, Dollinger MM. CD13: Waving the flag for a novel cancer stem cell target. Hepatology. 2011; 53: 1388-90.

117. Kim HM, Haraguchi N, Ishii H, Ohkuma M, Okano M, Mimori K, Eguchi H, Yamamoto H, Nagano H, Sekimoto M, Doki Y, Mori M. Increased CD13 expression reduces reactive oxygen species, promoting survival of liver cancer stem cells via an epithelial-mesenchymal transition-like phenomenon. Ann Surg Oncol. 2012; 19 Suppl 3: S539-48.

118. Dong C, Yuan T, Wu Y, Wang Y, Fan TW, Miriyala S, Lin Y, Yao J, Shi J, Kang T, Lorkiewicz P, St Clair D, Hung MC, et al. Loss of FBP1 by Snail-mediated repression provides metabolic advantages in basal-like breast cancer. Cancer Cell. 2013; 23: 316-31.

119. Park IJ, Lee YK, Hwang JT, Kwon DY, Ha J, Park OJ. Green tea catechin controls apoptosis in colon cancer cells by attenuation of $\mathrm{H} 2 \mathrm{O} 2$-stimulated $\mathrm{COX}-2$ expression via the AMPK signaling pathway at low-dose H2O2. Ann N Y Acad Sci. 2009; 1171: 538-44.

120. Du GJ, Lin HH, Xu QT, Wang MW. Bcl-2 switches the type of demise from apoptosis to necrosis via cyclooxygenase-2 upregulation in HeLa cell induced by hydrogen peroxide. Cancer Lett. 2006; 232: 179-88.

121. Cesario A, Rocca B, Rutella S. The interplay between indoleamine 2,3-dioxygenase 1 (IDO1) and cyclooxygenase (COX)-2 in chronic inflammation and cancer. Curr Med Chem. 2011; 18: 2263-71.

122. Harris RE. Cyclooxygenase-2 (cox-2) and the inflammogenesis of cancer. Subcell Biochem. 2007; 42: 93-126.

123. Sharma V, Dixit D, Ghosh S, Sen E. COX-2 regulates the proliferation of glioma stem like cells. Neurochem Int. 
2011; 59: 567-71.

124. Wang KH, Kao AP, Chang CC, Lee JN, Hou MF, Long CY, Chen HS, Tsai EM. Increasing CD44+/CD24(-) tumor stem cells, and upregulation of COX-2 and HDAC6, as major functions of HER2 in breast tumorigenesis. Mol Cancer. 2010; 9: 288.

125. Singh B, Cook KR, Vincent L, Hall CS, Berry JA, Multani AS, Lucci A. Cyclooxygenase-2 induces genomic instability, BCL2 expression, doxorubicin resistance, and altered cancer-initiating cell phenotype in MCF7 breast cancer cells. J Surg Res. 2008; 147: 240-6.

126. Wang D, Dubois RN. Prostaglandins and cancer. Gut. 2006; 55: 115-22.

127. Greenhough A, Smartt HJ, Moore AE, Roberts HR, Williams AC, Paraskeva C, Kaidi A. The COX-2/PGE2 pathway: key roles in the hallmarks of cancer and adaptation to the tumour microenvironment. Carcinogenesis. 2009; 30: 377-86.

128. Jain S, Chakraborty G, Raja R, Kale S, Kundu GC. Prostaglandin E2 regulates tumor angiogenesis in prostate cancer. Cancer Res. 2008; 68: 7750-9.

129. Shao J, Sheng GG, Mifflin RC, Powell DW, Sheng H. Roles of myofibroblasts in prostaglandin E2-stimulated intestinal epithelial proliferation and angiogenesis. Cancer Res. 2006; 66: 846-55.

130. Castellone MD, Teramoto H, Williams BO, Druey KM, Gutkind JS. Prostaglandin E2 promotes colon cancer cell growth through a Gs-axin-beta-catenin signaling axis. Science. 2005; 310: 1504-10.

131. Ishimoto T, Oshima H, Oshima M, Kai K, Torii R, Masuko T, Baba H, Saya H, Nagano O. CD44+ slow-cycling tumor cell expansion is triggered by cooperative actions of Wnt and prostaglandin E2 in gastric tumorigenesis. Cancer Sci. 2010; 101: 673-8.

132. Dayem AA, Choi HY, Kim JH, Cho SG. Role of oxidative stress in stem, cancer, and cancer stem cells. Cancers (Basel). 2010; 2: 859-884.

133. Shi X, Zhang Y, Zheng J, Pan J. Reactive oxygen species in cancer stem cells. Antioxid Redox Signal. 2012; 16: 121528.

134. Dokic I, Hartmann C, Herold-Mende C, Regnier-Vigouroux A. Glutathione peroxidase 1 activity dictates the sensitivity of glioblastoma cells to oxidative stress. Glia. 2012; 60: 1785-800.

135. Li HJ, Reinhardt F, Herschman HR, Weinberg RA. Cancerstimulated mesenchymal stem cells create a carcinoma stem cell niche via prostaglandin E2 signaling. Cancer Discov. 2012; 2 : 840-55.

136. Lubos E, Kelly NJ, Oldebeken SR, Leopold JA, Zhang YY, Loscalzo J, Handy DE. Glutathione peroxidase-1 deficiency augments proinflammatory cytokine-induced redox signaling and human endothelial cell activation. J Biol Chem. 2011; 286: 35407-17.

137. Felice F, Lucchesi D, di Stefano R, Barsotti MC, Storti E, Penno G, Balbarini A, Del Prato S, Pucci L. Oxidative stress in response to high glucose levels in endothelial cells and in endothelial progenitor cells: evidence for differential glutathione peroxidase-1 expression. Microvasc Res. 2010; 80: 332-8.

138. Galasso G, Schiekofer S, Sato K, Shibata R, Handy DE, Ouchi N, Leopold JA, Loscalzo J, Walsh K. Impaired angiogenesis in glutathione peroxidase-1-deficient mice is associated with endothelial progenitor cell dysfunction. Circ Res. 2006; 98: 254-61.

139. Zhu TS, Costello MA, Talsma CE, Flack CG, Crowley JG, Hamm LL, He X, Hervey-Jumper SL, Heth JA, Muraszko KM, DiMeco F, Vescovi AL, Fan X. Endothelial cells create a stem cell niche in glioblastoma by providing NOTCH ligands that nurture self-renewal of cancer stemlike cells. Cancer Res. 2011; 71: 6061-72.

140. Gursel DB, Berry N, Boockvar JA. The contribution of Notch signaling to glioblastoma via activation of cancer stem cell self-renewal: the role of the endothelial network. Neurosurgery. 2012; 70: N19-21. 